\title{
IMPACT OF DIETARY SUPPLEMENTATION WITH MULTI ENZYME AND/OR PROBIOTIC ON GROWTH PERFORMANCE, NUTRIENTS DIGESTIBILITY AND BLOOD CONSTITUENTS OF GROWING RABBITS
}

\author{
H. M. El-Kelawy ${ }^{1}$ and M. I. El-Kelawy ${ }^{2}$ \\ ${ }^{1}$ Department of Animal and Poultry Production, Faculty of Technology and Development, Zagazig \\ University, Egypt. \\ ${ }^{2}$ Department of Poultry Production, Faculty of Agriculture (New Valley), Assiut University, Egypt.
}

(Received 16/2/2016, Accepted 13/4/2016)

\section{SUMMARY}

\begin{abstract}
A total of 60 weaned New Zealand White rabbits at five weeks of age with an average body weight of $536 \pm 29.3 \mathrm{~g}$ were used in the present study. The study aimed to investigate the effect of feeding a basal commercial diet supplemented with either an enzyme complex (Kemzyme) or yeast preparation (Actisaf) or mixture of them on growth performance, nutrient utilization and health status of growing rabbits. The animals were divided into four equal experimental groups (each experimental group contains 15 rabbits distributed among 5 replicates, each containing 3 rabbits ) fed on four diets, basal commercial diet control (diet 1), control $+1 \mathrm{~g} / \mathrm{kg}$ diet Kemzyme (diet 2), control $+10 \mathrm{~g} / \mathrm{kg}$ diet Actisaf (diet 3 ) and control $+1 \mathrm{~g} / \mathrm{kg}$ diet Kemzyme $+10 \mathrm{~g} / \mathrm{kg}$ diet Actisaf $/ \mathrm{kg}$ (diet 4). At the 13 week of age, 5 rabbits from each experimental group were taken for the digestibility trial. The results of the study revealed that final live body weight, daily body gain and economical efficiency were significantly $(\mathrm{P}<0.01)$ higher with rabbits fed supplemented diets than those fed the control one. However, the previous parameters were the highest $(\mathrm{P}<$ 0.01 ) with rabbits fed diet 4. The daily weight gain values (at 5-13 weeks old) recorded 25.3, 27.5. 27.0 and $28.7 \mathrm{~g}$ for those fed the four diets, respectively. Feed conversion ratio (FCR) was significantly $(\mathrm{P}<0.01)$ improved with supplemented diets than control (3.97, 3.83. 3.88 and 3.70 for diets $1,2,3$ and 4, respectively. Apparent digestibility (\%) of DM, CP and DCP were improved by dietary supplementation. However, the improvement was significantly the highest $(\mathrm{P}<0.01)$ by rabbits fed Kemzyme + Actisaf supplemented diet (diet 4). In spite of the elevation of levels of blood plasma total protein, globulin, albumin and phagocytic activity by dietary supplementation, all blood biochemical and hematological parameters were within the normal physiological range. The results indicate that Kemzyme and Actisaf are good growth stimulators to the growing rabbits and can be added together to the commercial diet to improve feed utilization and growth performance without any adverse effects on health status of rabbits.
\end{abstract}

Keywords: Rabbits, multienzyme, probiotic, growth performance, digestibility and blood parameters.

\section{INTRODUCTION}

Monogastric animals such as rabbits are suffering from lack enzymes necessary to hydrolyze nonstarch polysaccharide components of plant cells in their foregut and this can lead to less utilization on nutrients and may even be a factor in clinical conditions such as nutritional diarrhea.

Several attempts were devoted to improve feed utilization and eliminate the indigestible feeds in the animal waste including use of probiotics, prebiotics, organic acids, enzymes and plant extracts (Onifade et al., 1998; Attia et al., 2012a; Attia et al., 2014a,b and Goli and Aghdam Shahryar, 2015).

Enzyme mixture could support the endogenous enzymes of the poultry and rabbits, break down some components of cell wall, which cannot be broken down into absorbable nutrients by endogenous enzymes (Abd El-Latif, et.al. 2008; Attia et al., 2012a and Attia et al., 2014a and b). Exogenous enzymes supplemented was nested to lowering the gastrointestinal viscosity in digestive tract (Simon, 2000), reducing nutrient entrapment and releasing other nutrients like minerals (Ibrahim et al., 2010), decreasing the anti-nutritional substances and improving animal performance (Abd El-Latif, et al 2008; El-Sagheer and Hassanein, 2014 and Goli and Aghdam Shahryar, 2015). Moreover, Latorre et al. (2014) suggested that higher amount of untraditional feedstuffs could be used in the presences of enzymes. The enhancement in body weight gain due to enzymes mixture supplementation was reported by Ibrahim et al. 


\section{El-Kelawy and El-Kelawy}

(2010) on growing rabbits and Attia et al. (2014a) on broilers. Ghazalah et al. (2005) reported that enzyme supplementation improved monogastric animal performance and reduce the energy formulation of the diets.

Yeast has been known as a probiotic added in the animal feed (Saegusa et al., 2004). Probiotics are live microorganisms that have many beneficial effects including promoting growth rate and enhancing protection against pathogenic gram positive and negative bacteria inside the intestine, through competitive exclusion, and lower the intestinal pH (Attia et al., 2011). Yeast also provides some essential nutrients such as vitamin B complex and many amino acids and aids in digestion by producing many enzymes. The inclusion of Saccharomyces cerevisiae in the diet of rabbits increased feed intake and growth of rabbits (Maertens and Ducatelle, 1996). Also, Saccharomyces cerevisiae was noted to improve protein digestion in domestic rabbits (Kamra et al., 1996). Onifade et al. (1998) observed the positive effect of Saccharomyces cerevisiae on weight gain, feed intake and feed conversation ratio in rabbits. Ezema and Eze(2012) suggested that Saccharomyces cerevisiae had a beneficial effect on growth and health status of rabbits. The growth rate of rabbits fed yeast supplemented diets was significantly $(\mathrm{P}<0.05)$ higher as compared to non-supplemented group irrespective of the housing systems (Khanna et al., 2014).

Therefore, the objective of this study was to assess the influence of dietary addition of Saccharomyces cerevisiae and enzymes on productive performance, digestibility of nutrients, blood biochemical and hematological traits of NZW rabbits.

\section{MATERIALS AND METHODS}

The present experiment was carried out in El-Behaira Governorate, Egypt. The present work lasted two month (from mid-December 2014 to mid-February 2015) in order to evaluate the effects of supplementation of multienzyme and probiotic in the basal diet on growth performance, blood biochemical parameters, and nutrient digestibility of weaning New Zealand White (NZW) rabbits. For this purpose, sixty male NZW rabbits, 5 weeks of age with an average initial body weight $536 \pm 29.33 \mathrm{~g}$ were randomly allotted into four experimental groups, each experimental group contains 15 rabbits distributed among 5 replicates, each containing 3 rabbits (cage). The $1^{\text {st }}$ group was used as control and fed only a basal pelleted ration without any supplementation of multienzyme or probiotic. Rabbits in the $2^{\text {nd }}$ , $3^{\text {rd }}$ and $4^{\text {th }}$ groups were fed respectively the basal pelleted ration supplemented with multienzyme (Kemzyme at $1 \mathrm{~g} / \mathrm{kg}$ diet), probiotic (10g Actisaf® yeast, i.e $107 \mathrm{CFU} / \mathrm{g} / \mathrm{kg} \mathrm{DM})$ and multienzyme plus probiotic (1g Kemzyme $/ \mathrm{kg}$ diet $+10 \mathrm{~g} / \mathrm{kg}$ Actisaf®), respectively. The enzyme complex preparation kemzyme was a product of Kemin Agrifoods Industry, Europian United and composed analysis of 300 $\mu / \mathrm{g}$ beta-glucanse , $5000 \mu / \mathrm{g}$ cellulase, $450 \mu / \mathrm{g}$ alfa amylase and $450 \mu / \mathrm{g}$ protease and lipase.

The Actisaf preparation was product of Lesaffree Feed additive, Marquette-Lez-Lille, France and composed of live yeast ( Saccharomyces cerevisiae), NCYC Sc 47, $10^{7}$ CFU/g of dry matter, coated with saccharides. The rabbits were housed in wire cages $(60 \times 55 \times 40 \mathrm{~cm})$ provided with galvanized feeders and automatic nipple drinkers. The experimental diets were offered to rabbits ad libtium and fresh tap water was available to rabbits all the time. Rabbits were kept under the same hygienic and environmental conditions during the experimental period. The experimental basal diet was formulated to meet the nutrient requirements of rabbits according to NRC (1977). Ingredients and chemical composition of the experimental diets are shown in Table (1).

During the growing period from 5 to 13 weeks, rabbit live body weight, daily weight gain (DWG), feed consumption and feed conversion ratio were weekly recorded. European Production Efficiency index was calculated as cited by Attia et al. (2012a). Economical evaluation for all experimental rations was calculated as described by Zeweil (1996).

At the 13 week of age, 5 rabbits from each experimental group were taken for the digestibility trial. A total number of 20 male rabbits were housed individually in metabolic cages that allow collected feces throughout the digestibility trial. Quantitative collection of feces was started 24 hours after offering the daily feed. Feces of each male rabbit were collected quantitatively once a day before the morning at 9.00 am and feed intake was recorded every day in the morning for 6 days as a collection period. Feces samples were stored at $-20^{\circ} \mathrm{C}$. The six days combined collections were sampled and the samples were kept for routine analysis. Feed samples was collected and prepared for proximate analysis. Fecal samples were dried at $65^{\circ} \mathrm{C}$ for 24 hours and ground through a $1 \mathrm{~mm}$ screen on a Wiley grinder. They were composited $50 \mathrm{gm}$ per sample per treatment per animal for analysis. The composite samples of the offered 
diet and dried feces of each rabbit were chemically analyzed for crude protein (CP), ether extract (EE), crude fibre (CF), nitrogen free extract (NFE) according to the method of A.O.A.C. (1995).

Table (1): Ingredients and chemical analysis of the experimental basal diet.

\begin{tabular}{llc}
\hline Item & & $\%$ \\
\hline & Yellow Corn & 6.22 \\
Soybean meal, 44\% & 22.33 \\
Wheat bran & 23.33 \\
Barley & 15.00 \\
Alfalfa hay & 30.12 \\
Ground limestone & 1.00 \\
Dicalcium Phosphate & 1.20 \\
Common salt & 0.50 \\
Vit. + Min. Premix ${ }^{*}$ & 0.30 \\
Total & 100.00 \\
Chemical analysis: & \\
Dry matter & 90.55 \\
Organic matter & 80.97 \\
Crude protein & 17.28 \\
Crude fiber & 13.26 \\
Ether extract & 2.69 \\
Nitrogen-free extract & 47.74 \\
Ash & 9.58 \\
Calculated digestible energy (kcal/kg diet)** & 2680 \\
Cell Wall Constituents (\%): & \\
Neutral detergent fiber (NDF) & 4.99 \\
Acid detergent fiber (ADF) & 2.85 \\
Hemicellulose & 2.14 \\
\hline
\end{tabular}

"Each $3 \mathrm{~kg}$ of premix contains: Vit. A:12,000,000 IU; Vit. D3: 3,000,000 IU; Vit. E:10.0 mg; Vit. K3: 3.0 mg; Vit. B1: 200 mg: Vit. B2: $5.0 \mathrm{mg}$ Vit. B6: $3.0 \mathrm{mg}$ : Vit. B12: $15.0 \mathrm{mg}$; Biotin: $50.0 \mathrm{mg}$; Folic acid: $1.0 \mathrm{mg}$; Nicotinic acid: $35.0 \mathrm{mg}$ : Pantothenic acid: $10.0 \mathrm{mg}$; $\mathrm{Mn}: 80 \mathrm{~g}$; Cu: $8.8 \mathrm{~g}$; Zn: $70 \mathrm{~g}$; Fe:35 g; I: $1 \mathrm{~g}$; Co: $0.15 \mathrm{~g}$ and Se: $0.3 \mathrm{~g}$.

** was calculated according to Carpenter and Clegg (1956).

NDF and ADF were calculated according to Cheeke (1987) where:

$\mathrm{NDF}=28.924+0.657(\% \mathrm{CF})$ and $\mathrm{ADF}=9.432+0.912(\% \mathrm{CF})$.

ME calculated according to Carpenter and Clegg (1956) by applying the equation:- ME (Kcal/kg)= $(35.3 * \mathrm{CP} \%)+(79.5 * \mathrm{EE} \%)+(40.6 * \mathrm{NFE} \%)+199$.

At the end of the experiment (at week 13 of age), six blood samples were collected from each treatment. Blood samples were collected from ear vein using sterilized syring needle and placed into a heparinized test tube. Blood plasma was obtained by centrifugation at 2500 r.p.m. for 15 minutes, and then stored in deep freezer at $-20{ }^{\circ} \mathrm{C}$ until biochemical tests.

Blood hemoglobin concentration $(\mathrm{g} / \mathrm{dl})$ was determined using hemoglobinometers as the method described by Tietz (1982). Red blood cell counts were counted on bright line hemocytometer using light microscope at $400 \mathrm{X}$ magnification. RBC's were counted according to the method of Hawkeye and Dennett (1989). White blood cell counts were counted according to the method of Hawkeye and Dennett (1989) using a light microscope at 100X magnification.

PCV (\%) was recorded directly according to Wintrobe (1965). Blood MCH and MCHC were determined according to the following equations of Jain (1986):

Mean corpuscular hemoglobin $(\mathrm{MCH}) \quad(\mathrm{Pg})=\mathrm{HbX10} / \mathrm{RBC}$ 's

Mean corpuscular hemoglobin concentration $(\mathrm{MCHC})(\mathrm{g} / \mathrm{dl})=\mathrm{HbX} 100 / \mathrm{PCV}$ 
Blood film was prepared according to the method described by Lucky (1977). Ten drops of any Gunwale stain stack solution with a dry, unfixed smear were added to equal amount of distilled water, then mixed and left for 1 minute for staining. The dye was de courted without rinsing. Diluted Giemsa's solution (10 drops of the dye were added to $10 \mathrm{ml}$ distilled water) was poured over the film as counter stain and left for 20 minutes, then rounded in water current and absolute value for each type of cells were counted and calculated relative to total WBC's. Phagocytic activity was determined according to Kawahara et al. (1991). Candida albicans culture $(50 \mu \mathrm{g})$ was added to $1 \mathrm{ml}$ of citrated blood and shaken in water bath at $23-25^{\circ} \mathrm{C}$ for 3-5 hr, smears of the blood were then stained with Giemsa solution. Phagocytic was estimated by determining the pro-portion of macrophages which contained intracellular yeast cell in a random count of 300 macrophages and expressed as percentage of phagocytic cells containing yeast cells (PA). The number of phagocytized organ-isms was counted in the phagocytic cells and expressed as number of yeast cells phagocytes/number of phagocytic cells (PI).

All blood biochemical parameters were determined using commercial kits (Diamond Diagnostics, Egypt) according to the following methods. Plasma total protein (Doumas et al., 1981), albumin (Doumas et al., 1971), Plasma globulin was obtained by subtracting the concentration of albumin from that of plasma total protein. Plasma creatinine (Fabiny and Ertingshausen, 1971), urea (Sampson et al., 1980), total lipids (Chabrol and Charonnat, 1973), total cholesterol (Allain et al., 1974), triglycerides (Bogen and Kaller, 1987), glucose (Hyvarinen and Nikkila, 1962) and ALP (Belfield and Goldberg, 1971) as well as activities of plasma transaminase ALT and AST were measured (Reitman and Frankel, 1957).

\section{Statistical analysis}

Data were statistically examined by analysis of variance (ANOVA) according to Snedecor and Cochran (1982) using SPSS system (2006). The differences between means were tested by using Duncan's New Multiple Range test (Duncan, 1955).

\section{RESULTS AND DISCUSSION}

\section{Effect of dietary supplementations on:}

\section{1- Growth performance parameters:}

Data in Table (2) show that average live body weight at 9 and 13veeks of age and daily weight gain, daily feed intake and feed conversion ratio from 5-9, 9-13 and 5-13 weeks of age were significantly improved $(\mathrm{P}<0.01)$ in rabbits fed the diet supplemented with multienzymes or probiotic than the control. Live body weight at 13 weeks of age and daily weight gain from 9-13 and 5-13 weeks of age were significantly higher $(\mathrm{P}<0.01)$ with rabbits fed multienzyme + probiotic diets that than those fed multienzyme or probiotic diets. Supplementation with multienzymes or probiotic improved $(\mathrm{P}<0.01)$ the economic efficiency and production index compared to control group. Rabbit fed diet supplemented with multienzymes plus probiotic had the best values of growth performance parameters, followed by those fed diet supplemented with multienzymes and probiotic, respectively. These findings are in agreement with those of Onifade et al. (1998), El-Kelawy et al. (2002), Onu and Oboke (2010) and Khanna et al. (2014) who found that the growth performance of the rabbits fed diet supplemented with yeast was significantly $(\mathrm{P}<0.05)$ higher as compared to the control one. In addition, live yeast, such as Saccharomyces cerevisia, contains numerous enzymes that could be released into the intestine and aid existing enzymes in the digestive tract in the digestion of feed (Kornegay et al., 1995). Moreover, yeast supplementation can inhibit pathogenic bacteria and increase the number of anaerobic and cellulolytic bacteria as reported by (Abd El-Azeem, 2002). Also, Yamani et al. (1992) found that, a pelleted diet supplemented with probiotic improved weight gain in NZW rabbits during the growing period. Sarhan (2001) found that under Egyptian conditions, feeding rabbits diet supplemented with $0.5 \mathrm{~g} / \mathrm{kg}$ of either Kemzyme or Optizyme (multi enzyme mixtures) significantly improved daily weight gain from 5 to 9 and from 5 to 13 weeks of age. Also, Makled et al., (2005) found that average daily feed intake of rabbits during the growth period from 6 to 12 weeks of experimental period was increased due to adding optizyme at a levels of 500 or $750 \mathrm{mg} / \mathrm{kg}$ feed. The enhancement in feed conversion efficiency as a result of adding enzymes may be due to the effect of enzymes in improving the digestibility of nutrients (El-Mandy et al., 2002). A significant increase in the average body weight was observed in growing rabbits supplemented with Kemzyme for 8 weeks (Attia et al., 2012b). Eiben et al. (2002) found that feeding rabbit's diet supplemented with cellulase enzymes significantly improved weight gain from 23 to 63 and from 63 to 77 days of age, by 17 and 3\%, respectively. Onu and Oboke (2010) reported that feed conversion ratio of rabbits fed diets supplemented with enzyme and probiotics were significantly superior 
over the other groups. Gutiérrez et al. (2002) showed that addition of enzymes has improved body weight gain of young rabbits, from 25 to 39 days of age by $3.1 \%$. El-Sagheer and Hassanein (2014) found that the addition of commercial enzyme mixture (Veta-zyme) at the level of $1 \mathrm{~g} / \mathrm{kg}$ commercial diet for growing female rabbit of different strains has a beneficial effect on growth performance due to improvement in body weight and body weight gain. Improvement in live body weight and body weight gain of the rabbits fed enzymes diet may be due to the enhancing effect of enzymes on microflora growth in the gut and caecum as well as increase in the volatile fatty acids production and organic matter digestibility (Abd El-Latif et al., 2008). In addition, adding a multienzymes product (Optizyme) which contain protease amyloglucosidase, xylanase,$\beta$ - glucanase, cellulase and hemicellulase monogastric animal diets suffer from under utilization of nutrients due to absence of enzymes necessary for hydrolyzing non-starch polysaccharides in the foregut that reduces the viscosity of intestinal content and improves nutrients absorption (Sullivan, 1987).

Table (2): Effect of supplementation with multienzymes or probiotic on growth performance of growing NZW rabbits.

\begin{tabular}{|c|c|c|c|c|c|}
\hline Item & $\begin{array}{l}\text { Control } \\
\text { (Diet 1) }\end{array}$ & $\begin{array}{c}\text { Multienzyme(MZ) } \\
\text { (Diet 2) }\end{array}$ & $\begin{array}{l}\text { Probiotic(Pro) } \\
\text { (Diet 3) }\end{array}$ & $\begin{array}{l}\text { MZ plus Pro } \\
\text { (Diet 4) }\end{array}$ & Sig. \\
\hline \multicolumn{6}{|l|}{ Live body weight $(\mathrm{g})$ : } \\
\hline Initial BW (5 weeks) & $529 \pm 4.22$ & $527 \pm 4.85$ & $546 \pm 9.98$ & $541 \pm 9.07$ & NS \\
\hline At 9 weeks & $1336^{\mathrm{b}} \pm 10.86$ & $1394^{\mathrm{a}} \pm 14.50$ & $1385^{\mathrm{a}} \pm 16.43$ & $1427^{\mathrm{a}} \pm 15.16$ & $* *$ \\
\hline Final BW (13 weeks) & $2049^{c} \pm 18.07$ & $2176^{\mathrm{b}} \pm 19.92$ & $2167^{\mathrm{b}} \pm 23.42$ & $2263^{\mathrm{a}} \pm 22.77$ & $* *$ \\
\hline \multicolumn{6}{|c|}{ Daily weight gain $(\mathrm{g})$ from: } \\
\hline 5-9 weeks & $26.93^{\mathrm{c}} \pm 0.23$ & $28.90^{\mathrm{a}} \pm 0.33$ & $27.98^{\mathrm{b}} \pm 0.25$ & $29.52^{\mathrm{a}} \pm 0.26$ & $* *$ \\
\hline 9-13 weeks & $23.74^{\mathrm{c}} \pm 0.25$ & $26.05^{\mathrm{b}} \pm 0.26$ & $26.06^{\mathrm{b}} \pm 0.24$ & $27.86^{\mathrm{a}} \pm 0.30$ & $* *$ \\
\hline 5-13 weeks & $25.33^{\mathrm{c}} \pm 0.23$ & $27.47^{\mathrm{b}} \pm 0.25$ & $27.02^{\mathrm{b}} \pm 0.24$ & $28.69^{\mathrm{a}} \pm 0.26$ & $* *$ \\
\hline \multicolumn{6}{|c|}{ Daily feed intake (g/day) from: } \\
\hline 5-9 weeks & $87.46^{\mathrm{c}} \pm 0.22$ & $90.33^{\mathrm{a}} \pm 0.25$ & $88.94^{\mathrm{b}} \pm 0.43$ & $90.52^{\mathrm{a}} \pm 0.40$ & $* *$ \\
\hline 9-13 weeks & $113.55^{\mathrm{b}} \pm 0.82$ & $119.76^{\mathrm{a}} \pm 0.97$ & $120.72^{\mathrm{a}} \pm 1.02$ & $121.62^{\mathrm{a}} \pm 1.00$ & $* *$ \\
\hline $5-13$ weeks & $100.51^{b} \pm 0.52$ & $105.05^{\mathrm{a}} \pm 0.58$ & $104.83^{\mathrm{b}} \pm 0.71$ & $106.07^{\mathrm{a}} \pm 0.68$ & $* *$ \\
\hline \multicolumn{6}{|c|}{ Feed conversion ratio(g feed/g gain) from age: } \\
\hline 5-9 weeks & $3.25^{\mathrm{a}} \pm 0.02$ & $3.13^{\mathrm{bc}} \pm 0.03$ & $3.18^{\mathrm{b}} \pm 0.02$ & $3.07^{\mathrm{c}} \pm 0.02$ & $* *$ \\
\hline 9-13 weeks & $4.78^{\mathrm{a}} \pm 0.02$ & $4.60^{\mathrm{b}} \pm 0.03$ & $4.63^{\mathrm{b}} \pm 0.01$ & $4.37^{\mathrm{c}} \pm 0.02$ & $* *$ \\
\hline 5-13 weeks & $3.97^{\mathrm{a}} \pm 0.02$ & $3.83^{\mathrm{c}} \pm 0.01$ & $3.88^{\mathrm{b}} \pm 0.01$ & $3.70^{\mathrm{d}} \pm 0.01$ & $* *$ \\
\hline \multicolumn{6}{|l|}{ Mortality (\%) from age : } \\
\hline $5-13$ weeks & 0.00 & 0.00 & 0.00 & 0.00 & \\
\hline \multicolumn{6}{|l|}{ Economic efficiency: } \\
\hline Feed cost & $16.89^{c} \pm 0.364$ & $17.78^{\mathrm{b}} \pm 0.403$ & $17.64^{\mathrm{b}} \pm 0.494$ & $18.14^{\mathrm{a}} \pm 0.473$ & $* *$ \\
\hline Total cost & $26.89^{c} \pm 0.364$ & $27.78^{\mathrm{b}} \pm 0.403$ & $27.64^{\mathrm{b}} \pm 0.494$ & $28.14^{\mathrm{a}} \pm 0.473$ & $* *$ \\
\hline Total revenue & $40.97^{c} \pm 1.40$ & $43.51^{\mathrm{b}} \pm 1.54$ & $43.35^{\mathrm{b}} \pm 1.81$ & $45.25^{\mathrm{a}} \pm 1.76$ & $* *$ \\
\hline Net revenue & $14.08^{\mathrm{c}} \pm 1.04$ & $15.74^{\mathrm{b}} \pm 1.14$ & $15.71^{\mathrm{b}} \pm 1.32$ & $17.12^{\mathrm{a}} \pm 1.29$ & $* *$ \\
\hline Economic efficiency & $52.32^{c} \pm 3.11$ & $56.61^{\mathrm{b}} \pm 3.24$ & $56.79^{\mathrm{b}} \pm 3.73$ & $60.77^{\mathrm{a}} \pm 3.55$ & $* *$ \\
\hline Production index & $61.46^{c} \pm 2.98$ & $67.52^{\mathrm{b}} \pm 3.26$ & $66.52^{\mathrm{b}} \pm 3.21$ & $71.96^{\mathrm{a}} \pm 3.49$ & $* *$ \\
\hline
\end{tabular}

Means in the same row within the same classification having different letters are significantly differ $(P<0.05)$.

$N S=$ not significant, $\quad * *=P<0.01$.

\section{2- Digestibility and nutritive values:}

Data in Table (3) show that the average of digestibility coefficient of DM was significantly improved (P < $0.05)$ with rabbits fed basal diet supplemented with multienzymes plus probiotic than those fed the control diet. Moreover, digestibility coefficient of CP and DCP were significantly $(\mathrm{P}<0.01)$ higher with rabbits fed multienzymes plus probiotic diet or multienzymes alone compared with those fed the control diet. Moreover, rabbits fed diets multienzymes or probiotic had higher $(\mathrm{P}<0.05)$ NFE than those fed the control diet. However, the differences in OM, EE, CF, NDF, ADF and TDN were insignificantly. The improvement in digestibility coefficients DM, CP and NFE of rabbits fed enzymes or probiotic diets, may be due to the enhancing effect of enzymes on microflora growth in the gut and caecum as well as increase in volatile fatty acids production and organic matter digestibility (Abd El-Latif et al., 2008). Also, the enzymes may improve the release of cell bound nutrients; improve the activity of gut ecology and 
nutritive values expressed as DCP, TPN and DE (Makled et al., 2005). Onu and Oboke (2010) reported that the higher crude protein digestibility observed in rabbits fed probiotic and enzyme supplemented diets compared to those fed the control and unsupplemented diets may have been responsible for the higher weight gain of the rabbits fed these diets.

Table (3): Effect of dietary supplementation with multienzymes or probiotic on the apparent nutrients digestibility and feeding value of the experimental diets by NZW rabbits.

\begin{tabular}{cccccc}
\hline Item & $\begin{array}{c}\text { Control } \\
(\text { Diet 1) }\end{array}$ & $\begin{array}{c}\text { Multienzyme(MZ) } \\
(\text { Diet 2) }\end{array}$ & $\begin{array}{c}\text { Probiotic(Pro) } \\
(\text { Diet 3) }\end{array}$ & $\begin{array}{c}\text { MZ plus Pro } \\
(\text { Diet 4) }\end{array}$ & Sig. \\
\hline \multicolumn{7}{c}{ Apparent nutrients digestibility (\%): } & & & & \\
DM & $62.1^{\mathrm{b}} \pm 1.43$ & $69.0^{\mathrm{a}} \pm 2.45$ & $65.0^{\mathrm{ab}} \pm 5.06$ & $67.0^{\mathrm{ab}} \pm 4.20$ & $*$ \\
$\mathrm{OM}$ & $64.7 \pm 1.63$ & $69.9 \pm 5.69$ & $66.7 \pm 4.80$ & $68.6 \pm 4.15$ & $\mathrm{NS}$ \\
$\mathrm{CP}$ & $72.9^{\mathrm{b}} \pm 1.22$ & $75.8^{\mathrm{a}} \pm 0.84$ & $74.7^{\mathrm{ab}} \pm 2.54$ & $76.6^{\mathrm{a}} \pm 0.83$ & $* *$ \\
$\mathrm{EE}$ & $47.1 \pm 1.98$ & $48.9 \pm 1.60$ & $47.2 \pm 2.07$ & $46.6 \pm 3.13$ & $\mathrm{NS}$ \\
$\mathrm{CF}$ & $42.8 \pm 3.68$ & $46.0 \pm 5.27$ & $44.4 \pm 6.61$ & $47.6 \pm 7.05$ & $\mathrm{NS}$ \\
$\mathrm{NDF}$ & $57.1 \pm 2.42$ & $59.2 \pm 3.46$ & $58.1 \pm 4.34$ & $60.2 \pm 4.63$ & $\mathrm{NS}$ \\
$\mathrm{ADF}$ & $48.5 \pm 3.35$ & $51.4 \pm 4.80$ & $50.0 \pm 6.03$ & $52.8 \pm 6.43$ & $\mathrm{NS}$ \\
$\mathrm{NFE}$ & $68.6^{\mathrm{b}} \pm 1.46$ & $73.5^{\mathrm{a}} \pm 0.73$ & $72.0^{\mathrm{a}} \pm 4.22$ & $74.0^{\mathrm{a}} \pm 1.70$ & $*$ \\
Nutritive value as & & & & & \\
TDN & $57.1 \pm 2.03$ & $60.4 \pm 0.80$ & $58.9 \pm 3.48$ & $60.8 \pm 1.66$ & $\mathrm{NS}$ \\
DCP & $11.8^{\mathrm{b}} \pm 0.20$ & $12.4^{\mathrm{a}} \pm 0.23$ & $12.1^{\mathrm{ab}} \pm 0.42$ & $12.4^{\mathrm{a}} \pm 0.13$ & $* *$ \\
\hline
\end{tabular}

Means in the same row within the same classification having different letters are significantly differ $(P<0.05)$. $N S=$ not significant, $* *=P<0.01$.

\section{3- Blood biochemical components and hematological parameters:}

Data presented in Table (4) show that level of blood plasma total protein was significantly $(\mathrm{P}<0.01)$ higher in the rabbits fed the multienzymes plus probiotic diet than those fed the control or probiotic diets. Moreover, globulin and globulin/albumin ratio were significantly $(\mathrm{P}<0.01$ or $\mathrm{P}<0.05)$ higher with rabbits fed multienzymes or probiotic diets than those fed basal diet (control). Also, rabbits fed diet supplemented with multienzymes plus probiotic or multienzymes alone had significantly $(\mathrm{P}<0.01)$ higher plasma glucose than those fed basal diet (control) or basal diet supplemented with probiotic alone. Multienzymes plus probiotic and multienzymes alone had significantly $(\mathrm{P}<0.01)$ lower plasma urea than the probiotic alone. However, the differences in blood plasma albumin, total lipids, cholesterol, creatinine, urea/creatinine ratio, AST, ALT, AST/ALT ratio and alkaline phosphates were insignificant. Data presented in Table (4) show that all hematological parameters were not affected by either multienzymes or probiotic, except the RBC's, which was higher $(\mathrm{P}<0.05)$ in rabbits fed basal diet (control) than those fed probiotic diet. Rabbits fed diet supplemented with multienzymes plus probiotic or multienzymes alone had significantly higher PA\% than those fed basal diet (control). On the other hand, there was no significant effect of all supplementations on white blood cells and differential leukocytes counts. Makled et al., (2005) indicated that increasing optizyme level to $750 \mathrm{mg} / \mathrm{kg}$ feed in rabbits diet insignificantly increased the concentration of total protein and significantly increased only when rabbit does were fed on diet containing $500 \mathrm{mg}$ Optizyme $/ \mathrm{kg}$ feed, this enhancement in total protein was also associated with the noticed improvement in CP digestibility. On the other hand, Veslin et al. (2003) found no significant change in the level of the total protein, albumin and globulin in the blood of rabbits supplemented with Protozin enzyme $(19 \mathrm{mg} / \mathrm{kg} \mathrm{diet})$ in the concentrate mixture. Also, El-Tantawy et al. (2001) found that rabbits total lipids were insignificantly affected with Kemzyme supplementation in rabbits fed diets supplemented with Kemzyme. A significant increase in blood glucose levels, total lipids and total protein were observed in growing rabbits supplemented with Kemzyme for 8 weeks (Attia et al., 2012b). 
Table (4): Effect of dietary supplementation with multienzymes or probiotic on some blood biochemical components and hematological parameters of growing NZW rabbits.

\begin{tabular}{|c|c|c|c|c|c|}
\hline Item & $\begin{array}{l}\text { Control } \\
\text { (Diet 1) }\end{array}$ & $\begin{array}{l}\text { Multienzymes } \\
\text { (MZ) (Diet 2) }\end{array}$ & $\begin{array}{l}\text { Probiotic (Pro) } \\
\text { (Diet 3) }\end{array}$ & $\begin{array}{l}\text { MZ plus Pro } \\
\text { (Diet 4) }\end{array}$ & Sig. \\
\hline \multicolumn{6}{|l|}{ Blood plasma components: } \\
\hline Total protein $(\mathrm{g} / \mathrm{dl})$ & $4.70^{\mathrm{b}} \pm 0.126$ & $5.08^{\mathrm{ab}} \pm 0.475$ & $5.03^{\mathrm{b}} \pm 0.266$ & $5.52^{\mathrm{a}} \pm 0.488$ & $* *$ \\
\hline Albumin (mg/dl) & $3.00 \pm 0.369$ & $2.72 \pm 0.117$ & $2.65 \pm 0.302$ & $2.83 \pm 0.082$ & NS \\
\hline Globulin (mg/dl) & $1.70^{\mathrm{b}} \pm 0.369$ & $2.37^{\mathrm{a}} \pm 0.554$ & $2.38^{\mathrm{a}} \pm 0.360$ & $2.68^{\mathrm{a}} \pm 0.426$ & $* *$ \\
\hline Albumin /Globulin ratio & $0.590^{\mathrm{b}} \pm 0.226$ & $0.878^{\mathrm{a}} \pm 0.235$ & $0.918^{\mathrm{a}} \pm 0.217$ & $0.945^{\mathrm{a}} \pm 0.137$ & $*$ \\
\hline Glucose $(\mathrm{mg} / \mathrm{dl})$ & $78.83^{\mathrm{b}} \pm 2.64$ & $87.17^{\mathrm{a}} \pm 7.60$ & $80.83^{\mathrm{b}} \pm 4.75$ & $89.17^{\mathrm{a}} \pm 3.19$ & $* *$ \\
\hline Total lipid (mg/dl) & $106.4 \pm 6.96$ & $104.9 \pm 7.71$ & $98.80 \pm 4.99$ & $100.7 \pm 3.76$ & NS \\
\hline Cholesterol (mg/dl) & $203.3 \pm 3.88$ & $206.3 \pm 3.20$ & $201.5 \pm 5.21$ & $202.0 \pm 6.75$ & $\mathrm{NS}$ \\
\hline Urea (g/dl) & $17.22^{\mathrm{ab}} \pm 0.779$ & $16.42^{\mathrm{b}} \pm 0.917$ & $18.00^{\mathrm{a}} \pm 0.894$ & $16.67^{\mathrm{b}} \pm 1.03$ & $*$ \\
\hline Creatinine (g/dl) & $0.89 \pm 0.128$ & $0.97 \pm 0.197$ & $0.86 \pm 0.143$ & $0.90 \pm 0.089$ & NS \\
\hline Urea/creatinine ratio & $19.71 \pm 3.14$ & $17.61 \pm 3.76$ & $21.35 \pm 2.52$ & $18.72 \pm 2.66$ & NS \\
\hline AST (IU/L) & $59.11 \pm 4.08$ & $61.08 \pm 3.61$ & $57.15 \pm 1.92$ & $58.50 \pm 1.97$ & NS \\
\hline ALT (IU/L) & $69.50 \pm 1.22$ & $69.92 \pm 4.01$ & $67.50 \pm 1.76$ & $69.42 \pm 1.56$ & NS \\
\hline AST/ALT ratio & $0.85 \pm 0.069$ & $0.87 \pm 0.041$ & $0.85 \pm 0.38$ & $0.84 \pm 0.029$ & NS \\
\hline $\begin{array}{l}\text { Alkaline phosphates } \\
\text { (IU/L) }\end{array}$ & $13.17 \pm 1.17$ & $12.67 \pm 1.37$ & $12.33 \pm 1.97$ & $13.00 \pm 2.19$ & NS \\
\hline \multicolumn{6}{|l|}{ Hematological parameters: } \\
\hline Hemoglobin (g/dl) & $10.00 \pm 1.41$ & $9.67 \pm 1.03$ & $9.83 \pm 0.75$ & $9.83 \pm 0.98$ & NS \\
\hline Paced cells volume $(\%)$ & $29.17 \pm 2.71$ & $29.50 \pm 2.81$ & $29.83 \pm 2.23$ & $29.50 \pm 2.07$ & NS \\
\hline $\mathrm{MCV}($ micron3/RBC) & $179.4 \pm 21.3$ & $202.6 \pm 29.0$ & $217.5 \pm 17.6$ & $195.3 \pm 20.3$ & $\mathrm{NS}$ \\
\hline $\mathrm{MCH}(\mathrm{Ug})$ & $61.45 \pm 9.20$ & $66.34 \pm 9.62$ & $71.62 \pm 4.97$ & $65.20 \pm 9.09$ & NS \\
\hline $\mathrm{MCHC}(\%)$ & $34.32 \pm 4.13$ & $32.75 \pm 0.98$ & $32.97 \pm 0.87$ & $33.29 \pm 1.39$ & NS \\
\hline WBC's $\left(10^{3} / \mathrm{mm}^{3}\right)$ & $25.00 \pm 1.41$ & $23.50 \pm 1.05$ & $23.83 \pm 1.33$ & $24.33 \pm 1.03$ & NS \\
\hline \multicolumn{6}{|c|}{ Differential leucocytes counts: } \\
\hline Monocytes $\left(10^{3}\right)$ & $4.83 \pm 0.983$ & $4.33 \pm 0.516$ & $4.33 \pm 0.520$ & $3.83 \pm 0.408$ & NS \\
\hline Basophils $\left(10^{3}\right)$ & $0.83 \pm 0.408$ & $0.67 \pm 0.516$ & $0.67 \pm 0.515$ & $0.83 \pm 0.753$ & NS \\
\hline Eosinophils $\left(10^{3}\right)$ & $8.83 \pm 0.753$ & $9.67 \pm 1.033$ & $9.00 \pm 1.41$ & $9.50 \pm 0.548$ & NS \\
\hline Neutrophils $\left(10^{3}\right)$ & $48.67 \pm 1.51$ & $48.67 \pm 2.34$ & $50.67 \pm 1.97$ & $50.50 \pm 1.64$ & $\mathrm{NS}$ \\
\hline Lymphocytes $\left(10^{3}\right)$ & $36.83 \pm 1.47$ & $36.67 \pm 1.21$ & $35.33 \pm 1.22$ & $35.33 \pm 1.21$ & $\mathrm{NS}$ \\
\hline Heterophils /Lym. & $1.32 \pm 0.081$ & $1.33 \pm 0.095$ & $1.44 \pm 0.099$ & $1.43 \pm 0.088$ & $\mathrm{NS}$ \\
\hline Phagocytic activity (\%) & $16.33^{\mathrm{b}} \pm 0.816$ & $16.50^{\mathrm{a}} \pm 1.64$ & $17.83^{\mathrm{ab}} \pm 1.17$ & $18.67^{\mathrm{a}} \pm 1.75$ & $*$ \\
\hline Phagocytic index (\%) & $1.85 \pm 0.187$ & $1.83 \pm 0.207$ & $1.75 \pm 0.187$ & $1.80 \pm 0.126$ & NS \\
\hline
\end{tabular}

Means in the same row within the same classification having different letters are significantly differ $(P<0.05)$.

NS $=$ not significant $\quad *=P<0.05 \quad * *=P<0.01$.

\section{CONCLUSION}

1) Kemzyme and Actisaf are good growth stimulators to the growing rabbits and can be added to the commercial diet to improve feed utilization and growth performance traits without any adverse effects on health status of rabbits.

2) Dietary supplementation with a mixture of $1 \mathrm{~g} / \mathrm{kg}$ of Kemzyme (commercial multienzymes preparation) and $10 \mathrm{~g} / \mathrm{kg}$ of Actisaf (commercial yeast preparation) is recommended to obtain the best results of growth performance rather than adding each preparation individually.

\section{REFERENCES}

Abd El-Azeem, F. (2002). Digestion, neomycin and yeast supplementation in broiler diets under Egyptian summer conditions. Egyptian Poultry Science, 22: 235-257.

Abd El-Latif, S.A., Kh.A. Mohammed, Kawsar A. Ghaly and Maha A. Abd El-Latif (2008). Effect of using commercial enzymes on performance and some metabolic functions of rabbits fed grade levels of crude fiber. Egyptian Poultry Science, 28: 1003-1022. 


\section{El-Kelawy and El-Kelawy}

Allain C.A., L.S. Poon, C.S.G. Chang, W. Richmond and P.C. Fu (1974). Enzymatic determination of total serum cholesterol. Clinical Chemistry J., 20: 470-475.

AOAC (1995). Association of Official Analytical Chemists. Official methods of analysis, $16^{\text {th }}$ Ed, Washington, DC, USA.

Attia, Y.A., R.A. Hassan, A.E. Tag El-Din and B.M. Abou-Shehema (2011). Effect of ascorbic acid or increasing metabolizable energy level with or without supplementation of some essential amino acids on productive and physiological traits of slow-growing chicks exposed to chronic heat stress. J. of Anim. Physiol. and Anim. Nutr., 95(6):744-55.

Attia, Y.A., W.S. El-Tahawy, A.E Abd El-Hamid, S.S. Hassan, A. Nizza and M.I. El-Kelaway (2012a). Effect of phytate with or without multienzymes supplementation on performance and nutrient digestibility of young broiler chicks fed mash or crumble diets. Italian J. Anim. Sci., 11: 303-308.

Attia. K.A., Y.S. Sohair, S. Abd ElhamidSafaa, A. ZakiAmal and El-Sawy A. Mohamed (2012b). Effects of exogenous multi-enzyme feed additive (Kemzyme) on the activities of certain digestive enzymes and intestinal morphology in growing rabbits. J. of Agric. Sci., 4: 35-44.

Attia, Y.A., W.S. El-Tahawy, A.E Abd El-Hamid, A. Nizza, F. Bovera, M.A. Al-Harthi and M.I. ElKelaway (2014a). Effect of feed form, pellet diameter and enzymes supplementation on growth performance and nutrient digestibility of broiler during days 21-37 of age. Archiv Tierzucht, 57(34): $1-11$.

Attia, Y.A., W.S. El-Tahawy, A.E Abd El-Hamid, A. Nizza, M.I. El-Kelaway, M.A. Al-Harthi and F. Bovera (2014b). Effect of feed form, pellet diameter and enzymes supplementation on carcass characteristics, meat quality,blood plasma constituents and stress indicators of broilers. Archiv. Tierzucht, 57(30): 1-14.

Belfield, A. and D.M. Goldberg (1971). Revised assay for serum phenyl phosphatase activity using 4amino-antipyrine. Enzyme, 12(5): 561-573.

Bogen, E. and P. Kaller (1987). Application of chemical biochemistry to medically relevant animal models and standardization and quality control in animal biochemistry. J. clinical chemistry clinical biochemistry, 25:873-878.

Carpenter, K.J. and K.M. Clegg (1956). The metabolisable energy of poultry feeding stuffs in relation to their chemical composition. J. Sci. Food Agric., 7: 45-51.

Chabrol, E. and R. Charonnat (1973). Determination of total lipids. Press. Medical, 45: 1713-1720.

Cheeke, P.R. (1987). Rabbit Feeding and Nutrition. Academic Press. Orlando, Florida, U.S.A.

Doumas, B.T., D.D. Bayse, R.J. Carter, T.Jr Peters and R. Schaffer (1981). Acandidate reference method for determination of total protein in serum. Clinical Chemistry J., 271: 1642-1650.

Doumas, B.T., W.A. Watson and H.G. Biggs (1971). Albumin standards and the measurement of serum albumin with bromocresol green. Clinical Chemistry Acta, 31: 87-96.

Duncan, D.B. (1955). Multiple range and multiple F-test. Biometrics, 11: 1-42.

Eiben, C.S., N. Szijártó, M. Mézes, K. Kustos, K. Gódor-surmann and K. Réczey (2002). Effect of dietary cellulase enzyme supplementation on the performance of early weaned rabbits. $14^{\text {th }}$ Hungarian Conference on Rabbit Production, Kaposvár (Hungary), World Rabbit Science, 10:176 (Abstract).

El-Kelawy, H. M., M. A. Sarhan, A.S. Shehata and A. A. Abdel-Ghany (2002) Partial replacement of soybean meal by dried yeast in diets of growing Bouscat rabbits. $3^{\text {rd }}$ Sci. Con. On rabbit production in hot climates, 8-11 Oct.: 765-778.

El-Mandy, M.R., F.A. Salem and Y.M. EL-Homeland (2002). Effect of Kemzyme in rabbit ration differing in their protein levels on digestion, blood constituents and carcass traits. $3^{\text {rd }}$ conference on rabbit production in hot climates, Hurghada ( Egypt ), 495 - 505 .

El-Sagheer, M. and H.H.M. Hassanein (2014). Effect of enzymes and probiotic mixture supplementation to the diet of growing female rabbits on performance and carcass criteria. Egyptian Poultry Science, 34: 259-272. 
El-Tantawy, S., Samia Z. Meshreky, Fadia M. Nosseir and F. Hanna (2001). Effect of some feed additive on: productive performance carcass traits and some blood constituents of growing Bouscat rabbits. Egyptian J. Nutr and feed. 4, (special issue): 931-943.

Ezema, C. and D.C. Eze (2012). Determination of the effect of probiotic (Saccharomyces cerevisiae) on growth performance and hematological parameters of rabbits. Comparative Clinical Pathology, 21(1): 73-76.

Fabiny D.L. and G. Ertingshausen (1971). Automated reaction rate method for the determination of serum creatinine with the CenterfiChem. Clinical Chemistry J., 17: 696-700.

Ghazalah, A.A., A.H. Abd El-Gawad, M.S. Soliman and Amany, W. Youssef (2005). Effect of enzyme preparation on performance of broilers fed cornsoybean meal based diets. Egyptian Poultry Science, 25: 295-316.

Goli, S and H. Aghdam Shahryar (2015). Effect of enzymes supplementation (Rovabio and Kemin) on some blood biochemical parameters, performance and carcass characterizes in broiler chickens. Iranian J. of Applied Anim. Sci., 5(1): 127-131.

Gutiérrez, I., A. Espinosa, J. García, R. Carabaño, and J.C. De Blas (2002). Effects of exogenous phytase on phosphorous and nitrogen digestibility in growing finishing rabbits. In Proc.: $7^{\text {th }}$ World Rabbit Congress, Valencia, Spain, 277-281.

Hawkeye C.M. and T.B. Dennett (1989). A color Atlas of comparative veterinary hematology wolf. Publishing Limited, London, England.

Hyvarinen, A. and E.A. Nikkila (1962). Determination of blood glucose with O. Toludine. Nutrition abstracts and reviews, 32:589.

Ibrahim, M.R., H.M. El-Banna and M.A. ElManylawi (2010). Evaluating utilization of ground date stone meal with or without Kemzyme in the diets of growing New Zealand rabbits. IV International Date Palm Conference, 15-17 March, 2010, Abu-Dubi, UAE. Acta Hort. (ISHS) 882:691-697 http://www.actahort.org/books/882/882_75.htm.

Jain, N. C. (1986). Veterinary Haematology (Jain N C Ed) Lea and Ferbiger, Philadelphia.

Kamra, D.N., L.C. Chaudhary, R. Singh and N.N. Pathak (1996). Influence of feeding probiotics on growth performance and nutrient digestibility in rabbits. World Rabbit Science, 4: 85-88.

Kawahara, E., T. Ueda and S. Nomura (1991). In vitro phagocytic activity of white spotted shark cells after injection with Aermonas salmonicida extracellular products. Gyobokenkyu, Japan, 26: 213-214.

Khanna, S., H.K. Gulati, A.K. Verma, S.S. Sihag, D.P. Sharma and P.K. Kapoor (2014). Effect of yeast supplementation and alternative housing systems on performance of rabbits. Haryana Veterinary 53 (1): 23-27.

Kornegay, E.T., D. Rhein-Welker, M.D. Lindemann and C.M. Wood (1995). Performance and nutrient digestibility in weanling pigs as influenced by yeast culture additions to starter diets containing dried whey or one of two fiber sources. J. Anim. Sci., 73: 1381-1389.

Latorre, J.D., X. Hernandez-Velasco, M.H. Kogut, J.L. Vicente, R. Wolfenden, A. Wolfenden, B.M. Hargis, V.A. Kuttappan and G. Tellez (2014). Role of a Bacillus subtilis direct-fed microbial on digesta viscosity, bacterial translocation, and bone mineralization in turkey poults fed with a rye-based diet. Front. Veterinary Science 1:26.

Lucky, Z. (1977). Methods for the diagnosis of fish diseases. Ameruno Publishing Co., PVT, LTD. New Delhi, Bomby, New York.

Maertens L. and R. Ducatelle (1996). Tolerance of rabbits to a dietary overdose of live yeast (Biosaf Sc47). Resumenes del $6^{\text {th }}$ World Rabbit Congress, Toulouse, France, Vol. III Pp 95-98.

Makled, M.N., M.A. Metwally, I.A. Soliman and H.A. Younis (2005). Impact of different levels of dietary multienzymes supplement on california rabbit performance. $3^{\text {rd }}$ International Poultry Conference 4 -7 Apr. 2005 Hurghada - Egypt.

NRC (1977). National Research Council. Nutrition Requirements of Domestic animals. Nutrient Requirements of rabbits. $2^{\text {nd }}$ Rev. Ed. National Academy of Science, Washington, D.C. 
Onifade, A.A., R.I. Obiyan, E. Onipede, D.O. Adejumo, O.A. Abu and G.M. Babatunde (1998). Assessment of the effects of supplementing rabbit feeds with a culture of Saccharomyces cerevisiae using growth performance, blood composition and clinical enzyme activities. Animal Feed Science and Technology, 77(1): 25-32.

Onu, P.N. and S.A. Oboke (2010). Evaluation of enzyme and probiotic supplementation of maize processing waste-based diets on performance and nutrient utilization of weaner rabbits. Indian J. of Animal Research, 44 (2): 87 - 93.

Reitman, S. and S. Frankel (1957). A Method for determination of enzymatic activities. American J. of Clinical Pathology, 287: 56-58.

Saegusa, S., M. Totsuka, S. Kaminogawa and T. Hosoi (2004). Candida albicans and Sacchromyces cerevisiae induce interlukin- 8 production from intestinal epithelial-like Caco-2.

Sampson, E.J., M.A. Baird, C.A. Burtis, E.M. Smith, D.L. Witte and D.D. Bayse (1980). A coupledenzyme equilibrium method for urea measuring in serum: optimization and evaluation of the AACC study group on urea candidate refrence method. Clinical Chemistry J., 26 (7): 816-826.

Sarhan, A. (2001). Effect of protein level and supplementation on enzyme preparation in diets of growing rabbits. Egyptian J. Nutr. and Feeds. 4: 832 - 843.

Simon, O. (2000). Non starch polysaccharides (NSP) hydrolyzing enzyme as feed additions. Male of action in the gastro intestinal tract. Lohman Information, 23: 7-13.

Snedecor G.W. and W.G. Cochran (1982). Statistical Methods. $7^{\text {th }}$ Edition, Iowa State University, Press Ames, USA.

SPSS (2006). SPSS User's Guide Statistics. Version 10. Copyright SPSS Inc., USA.

Sullivan, L.M. (1987). Evaluation of sorghum varieties in poultry diets. Feed Facts. Published by grain sorghum producers. Association, vol. 4, no. 2.

Tietz, N.W. (1982). Fundamental of clinical chemistry Edition by Nobert Sounder Comp., Philadelphia, USA.

Veslin R., S. Kina and E. Encho (2003). Changes in Hematological parameters of rabbits given multienzyme Protozin in the diet. Trakia J. of Sci., 1 (1): $67-71$.

Wintrobe P.M. (1965). Clinical Hematology. Lead and Febiger. Philadelphia, USA.

Yamani, K.A., H. Ibrahim, A.A. Rashwan and K.M. El-Gendy (1992). Effects of a pelleted diet supplemented with probiotic (LactoSacc) and water supplemented with a combination of probiotic and acidifier (Acid-Pak 4Way) on digestibility, growth carcass and physiological aspects of weanling New Zealand White rabbits. J. of Applied Rabbit Research 15:1087-1100.

Zeweil H.S. (1996). Enzyme supplements to diets growing Japanese quails. Egyptian Poultry Sci. J., 16 (III): 535-557. 
تأثير إضافة الإنزيمات أو البروبيوتيك على معل أداء النمو، هضم المركبات الغذائية، ومكونات الام في الأرانب النامية

\author{
حسن محمود الكيلاوي 1و محمود إبراهيم الكيلاوي²

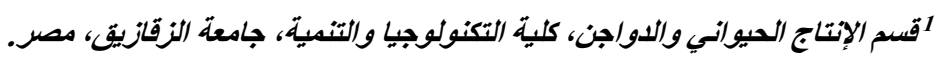

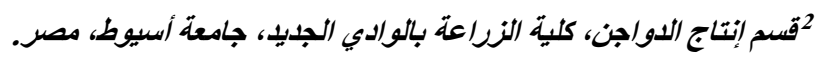

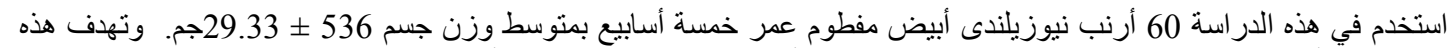

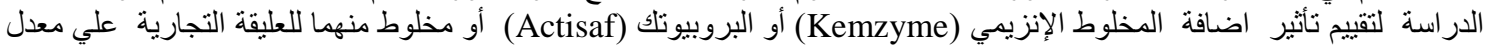

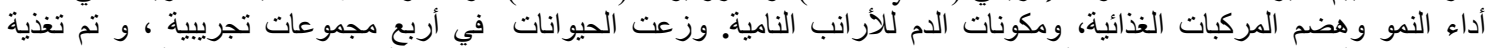

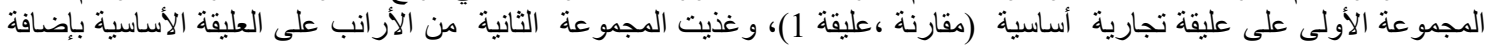

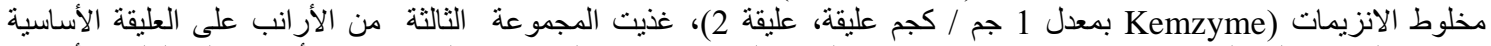

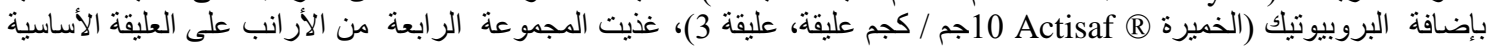

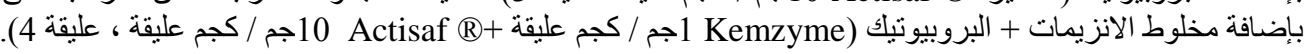

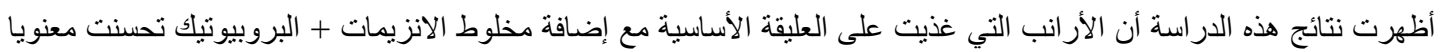

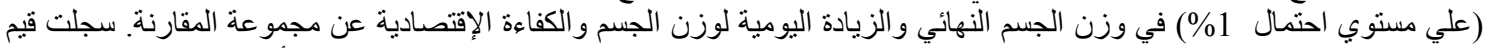

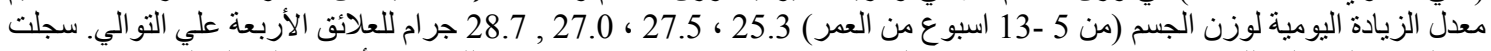

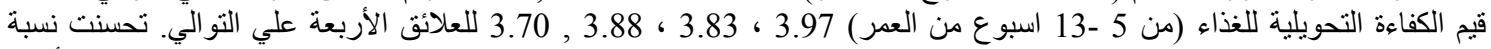

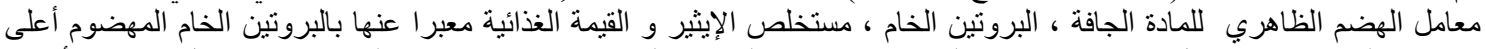

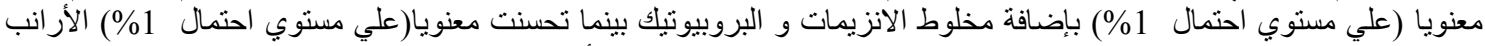

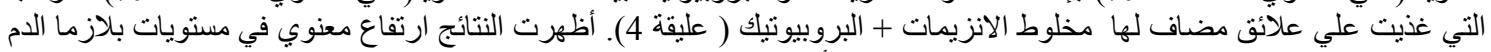

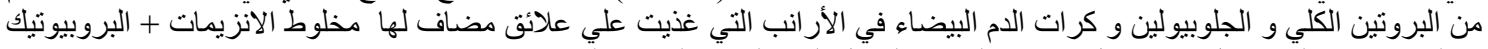

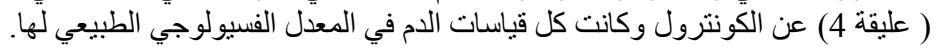

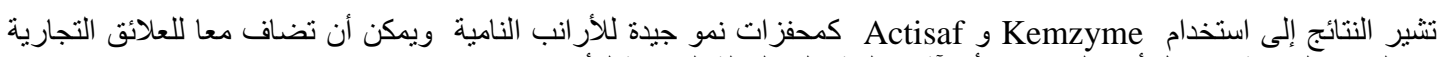

لتحسين الكفاءة الغذائية و معدل أداء النمو دون أي آثار سلبية على الحالة الصحية للأرانب. 